\title{
Winter Quarterly Meeting, 1986
}

The Winter Quarterly Meeting and the Maudsley Bequest Lectures were held at The Royal Society, London SW1 on 21 and 22 January 1986, under the Presidency of Dr Thomas Bewley.

\section{Regiturar's Report}

It is some two months since I presented my last Report, and in that time the Executive and Finance Committee has met twice and Council once.

Our priority task at present is to prepare the College's response to the Mental Health Act 1983 Draft Code of Practice. Many of you will have seen this, a bulky document of some 237 pages. I would like to spend a few minutes explaining how the College will be collating the response to this draft-a document of extreme significance which will affect the clinical practice, not only of our members, but also general practitioners and many other doctors. The President's request for an extended consultation period was agreed by the DHSS, and we have until the end of June to prepare our comments.

As I explained in my last Report (Bulletin, January 1986, 10, 17), Council has convened a Special Committee to collate our response. We received the Report on 19 December; fortuitously this coincided with the first meeting of the Committee. By 20 December the College Secretariat had arranged for copies to be sent to Divisions, Specialist Sections and relevant College Committees, requesting that they return their comments, in some cases by 17 January 1986, but in general by 1 March.

Members of the Special Committoe had a busy holiday period preparing their own detailed individual comments, and when they meet on 4 and 5 February a preliminary response will have been prepared, to which will be added the comments of the Divisions and Sections. The Draft Response will then be circulated widely at the end of March, so that it can be further refined well in advance of the June deadline for comments. Council agreed to the expenditure of obtaining legal advice, both on the Draft Code and the College's comments, and this we shall do. If any member of the College has specific comments to make on the Draft Code, I would be grateful if they could send them to me by the 1 March 1986

I would like to bring to your attention some other important matters discussed last week by Council. The Child and Adolescent Psychiatry Specialist Section has revised and up-dated its 1978 document on the 'Role, Responsibilities and Work of the Child and Adolescent Psychiatrist'. Council accepted the document subject to only minor amendments. The Executive and Finance Committee will consider the amended document in February, and it will eventually be published in the Bulletin. It should be available from the College in the early Spring.
The Dependence/Addiction Group has applied for Section status and this was approved by Council. Council has also accepted Guidelines prepared by the Section for the Psychiatry of Mental Handicap on Consent to Medical and Surgical Treatment, Contraception, Sterilisation and Abortion in the Mentally Handicapped. These will be published in the Bulletin and are also available from the College on request.

Council approved a proposal from the Special (Political Abuse of Psychiatry) Committee to set up a meeting with other medical organisations to explore possible further action on Soviet abuse of psychiatry. This will be a closed meeting, but a summary of the proceedings will be published.

The President reported to Council on the progress of the appeal to establish a permanent Research Unit at the College. Planning permission to convert the caretaker's flat from residential to office use had now been obtained. An application for planning permission to build a second floor on the caretaker's flat for the Research Unit was being processed. This improvement scheme would cost the College in the area of $£ 108,000$. Council approved this expenditure. It was hoped that, if planning permission were granted, the work could be completed by October 1986.

The Court of Electors met in December and agreed that the Laughlin Prize should be awarded jointly to Dr J. B. Connelly and Dr G. E. Moss. They also approved the list of candidates successful in the Preliminary Test and the Membership Examination held in October/November165 candidates passed the Membership (53\%). Council has endorsed the recommendation from the Court of Electors that the term 'Preliminary Test' should no longer be used, and that the stages of the Examination should be described as Part I and Part II.

The Court has been discussing in detail the 'Guidelines for the Training of the General Psychiatrist in Psychotherapy', and it is anticipated that a final version will be approved in February and subsequently published in the Bulletin.

May I remind members that the College has an answering service which operates after $6 \mathrm{pm}$. This is a convenient and economical way of leaving requests for information, and the calls will be dealt with the following day by the appropriate member of staff.

I would like to thank on your behalf the staff of the College who worked so hard at Christmas time to get our copies of the Draft Code of Practice to your Divisions and Sections at the earliest possible date. Finally, I am sure that you would wish to congratulate Dr Philip Connell who was awarded a CBE in the New Year Honours List.

R. G. PrIEst, Registrar 
Introduction of Honorary Fellows

Professor Leon Eisenberg was unable to attend the Annual Meeting in July 1985 and was presented at this meeting.

Professor L. Eisenberg (introduced by Professor I. Kolvin) Professor Leon Eisenberg is renowned for an extraordinary range of accomplishments. He is, to borrow an archaism, the complete psychiatrist.

Leon Eisenberg's considerable promise was recognised at an early stage by one of the founding fathers of modern child psychiatry, Professor Leo Kanner. The qualities Kanner recognised in the young Eisenberg were those of a true intellectual, a superb communicator and an excellent capacity for clinical research. It is true that to a certain extent most of us are moulded by our teachers and it is not surprising that, reared in the invigorating climate of Johns Hopkins, Eisenberg absorbed into his life and work all the strengths of scientific discipline in clinical and research practice. Within a decade, he was a full Professor at Johns Hopkins and a colleague and collaborator of Leo Kanner. This potential was more widely recognised when soon he was elected as Chairman of the Child Psychiatry Section of the American Psychiatric Association. However, the horizons of a sub-specialty proved too narrow for someone of Leon Eisenberg's breadth of vision and ability. When I met him 17 years ago he was in his mid forties and by that time he had been a full Professor for eight years, six of them in Child Psychiatry at Johns Hopkins and two as Professor and Chairman in General Psychiatry at the Massachusetts General Hospital, Boston. By 1980 his immense talent allowed him to switch yet again to become Professor and Chairman of the Social Medicine Department at Harvard University Medical School.

He has been on the editorial board of about a dozen major journals covering child and general psychiatry, psychosomatics, paediatrics and social medicine and for 10 years was the editor of the Journal of Orthopsychiatry. His considerable talent led to great demands on his time from both the World Health Organization and the National Institute of Health and, of course, from many other bodies both in North America and Europe. Despite these many commitments he has over $\mathbf{2 0 0}$ publications, the following themes being particularly prominent: social deprivation; social factors in the major psychoses and mental handicap, psychiatric and general health care and prevention of ill health in different cultures; intelligence, race and class and psychopharmacology. In child psychiatry his interests have been in the psychoses, school phobia, behaviour disorders and hyperkinesis; adolescent problems and suicide. Recently he has shown an interest in the future of psychiatric research.

What about the man himself? Leon Eisenberg has always concerned himself with social and practical issues in his research. Over his career he has tended to identify with socially important but often politically unpopular themes, such as 'Prevention-a political slogan or an attainable goal? He is an exciting personality, always bubbling over with enthusiasm for new ideas. In Boston he has played a major role in integrating the different branches of psychiatry at the Massachusetts General Hospital and Harvard University. In that exercise he has always encouraged a broad eclectic philosophy. Just as his own career was promoted by Kanner, he in turn has heiped to realise the aspirations of the bright trainees who have flocked to sit at his feet and at all times he has proved responsive to their needs. In private one quickly becomes aware of his vast knowledge of the arts and literature. He is one of those lucky individuals who proves to be not only professionally successful but also a marvellous raconteur with a lively sense of humour.

These many qualities and achievements have been honoured in many ways, even in the United Kingdom. He was, for instance, awarded an honorary DSc in Manchester in 1974 and a Burroughs Wellcome Royal Society of Medicine Visiting Professorship in 1982. Recently our College added to these signs of international recognition. The College has welcomed one of the most complete and wise of the leaders of our profession to our Fellowship of Psychiatrists. President, it is with great pleasure I present to you, Professor Leon Eisenberg.

\section{Annual Elections Honorary Officers and Council}

Fellows and Members of the College are reminded of their rights in connection with the forthcoming elections for the offices of Dean, Registrar, Treasurer, Editor, Librarian and Sub-Deans. All Honorary Officers except the Treasurer, Dr C. M. B. Pare, who has served seven years, are eligible for re-election.

The nominating meeting of Council will be held on 19 March 1986, and the last date for receiving nominations will therefore be 16 April 1986. Nominations may also be submitted for vacancies for Elected Members of Council. The relevant Bye-Laws and Regulations are printed below.

\section{Extracts from Bye-Laws and Regulations}

Bye-LaW XII THE OTHER HONORARY OFFICERS

1. The Council shall, in accordance with the Regulations, make its nominations for the offices of Dean, Registrar, Treasurer, Editor, Librarian at the first meeting after the name of the President for the next ensuing College year has become known. Written nominations for the above Honorary Offices, accompanied in each case by the nominee's written consent to stand for election, may also be lodged with the Registrar at such time as may be prescribed by the Regulations, provided that each such 